\title{
Sistem Informasi $e$-Voting Pemilihan Kepala Desa Berbasis SMS Gateway (Studi Kasus Desa Talang Seleman)
}

\author{
Muhammad Assahur ${ }^{1}$, Fenando $^{2}$, Timur Dali Purwanto ${ }^{3}$ \\ assa.sib@gmail.com ${ }^{1}$, fenando_uin@radenfatah.ac.id ${ }^{2}$, timurdp_uin@ radenfatah.ac.id ${ }^{3}$ \\ ${ }^{1}$ Prodi Sistem Informasi, Fakultas Sains dan Teknologi, UIN Raden Fatah Palembang \\ ${ }^{2}$ Prodi Sistem Informasi, Fakultas Sains dan Teknologi, UIN Raden Fatah Palembang \\ ${ }^{3}$ Prodi Sistem Informasi, Fakultas Sains dan Teknologi, UIN Raden Fatah Palembang
}

Diterima: 10 Maret 2017 |Direvisi: 24 Maret 2017 |Disetujui: 18 April 2017

(c) 2017 Program Studi Sistem Informasi Fakultas Sains dan Teknologi,

Universitas Islam Negeri Raden Fatah Palembang, Indonesia

\begin{abstract}
Abstrak: Pemilihan kepala desa merupakan hal yang harus dilakukan karena berdasarkan peraturan perundang-undangan yang ada masa jabatan kepala desa ada batasnya sama halnya dengan presiden, kepala daerah dan jabatan lain. Tak menuntut kemungkinan di bidang pemilihan kepala desa juga menggunakan kemajuan teknologi informasi, seperti menerapkan pemungutan suara berbasis elektronik atau lebih dikenal dengan sebutan e-Voting. e-Voting telah berkembang di berbagai belahan dunia seperti belanda dan negara maju lainnya, e-voting dapat berupa sebuah aplikasi desktop ataupun halaman web dan e-Voting dapat dilakukan dengan desktop biasa. Dalam perkembangan teknologi informasi sekarang ini e-Voting dapat dikembangkan melalui perangkat seluler seperti SMS Gateway ataupun aplikasi android pada telepon pintar. Dengan memanfaatkan metode SMS Gateway pemungutan suara pada pemilihan diharapkan dapat mempermudah dan mempercepat proses pemilihan tanpa harus berada dan antri di tempat pemungutan suara (TPS) dan juga dapat menghemat biaya operasional pemilihan dan menyediakan informasi akurat kepada pemilih mengenai hasil dari pemungutan suara.
\end{abstract}

Kata Kunci: e-Voting, SMS Gateway, Metode Spiral

\begin{abstract}
The election of village heads is a matter that must be done because based on legislation that has a term of office the village head has a limit as well as the president, regional head and other positions. Not demanding the possibility in the field of village head election also using advances in information technology, such as implementing electronic-based voting or better known as e-Voting. $e$-Voting has developed in various parts of the world such as the Netherlands and other developed countries, e-voting can be a desktop application or web page and e-Voting can be done with a regular desktop. In the development of information technology now e-Voting can be developed through cellular devices such as SMS Gateway or android applications on smartphones. By utilizing the SMS Gateway method, voting at the election is expected to simplify and accelerate the selection process without having to be present and queuing at polling stations (TPS) and also can save election operational costs and provide voters with accurate information about the results of voting.
\end{abstract}

Keywords: e-Voting, SMS Gateway, Spiral Method

\section{PENDAHULUAN}

Berkembangnya Ilmu Pengetahuan dan Teknologi menyebabkan informasi pun berkembang pesat, sehingga diperlukan sarana dan prasarana yang dapat mencukupi kebutuhan akan informasi tersebut. Timbulnya berbagai informasi tersebut mendorong manusia untuk mencapai dan mengembangkan teknik-teknik baru agar pengolahan data dapat dilaksanakan dengan cepat, akurat, dan efisien. Menurut (Sutabri, 2012), berasumsi bahwa informasi adalah data yang telah diproses ke dalam suatu bentuk yang mempunyai 
arti bagi si penerima dan mempunyai nilai nyata dan terasa bagi keputusan saat itu atau keputusan mendatang. Lain lagi pendapat (Saputra, 2011), berpendapat informasi merupakan suatu data yang telah diolah dan disusun sedemikian rupa sehingga akan memiliki nilai, dan tentunya harus memberikan manfaat bagi seseorang yang menggunakannya. Informasi dihasilkan dari data, jika dilakukan siklus penggambaran.

Di beberapa wilayah dunia telah melakukan pemilihan dengan memanfaatkan teknologi informasi yang disebut e-voting, banyak metode yang dapat digunakan untuk membuat evoting seperti berbasis halaman web ataupun SMS Gateway. Namun penerapan e-voting ini tidaklah semudah membalikkan telapak tangan butuh usaha dan ilmu pengetahuan dari para pemilih dan pelaksana pemilihan, tetapi jika kita membuat sebuah prototype ataupun simulasi dari pemilihan elektronik (e-Voting) pada pemilihan dengan skala kecil memungkinkan sistem pemilihan ini dapat diterapkan. Jadi usaha untuk memberikan ilmu pengetahuan lebih pada masyarakat di Indonesia haruslah dilakukan jika pemilihan elektronik ini ingin diterapkan, karena dapat kita lihat kebanyakan negara maju di dunia disebabkan masyarakatnya memiliki pengetahuan yang baik dalam bidang IPTEK (Ilmu Pengetahuan dan Teknologi) seperti Jepang dan Rusia.

Pemilihan kepala desa di Desa Talang Seleman yang hampir 5 tahun silam yakni pada Maret 2011, pemilihan dilakukan dengan cara mencentang nomor urut atau nama calon kepala desa. Pertama Sekretaris Desa menerima surat edaran (Surat Perintah) dari Camat dalam hal ini Kecamatan Payaraman, agar supaya melakukan pemilihan dengan memberikan tugas pembentukan panitia pemilihan kepada BPD (Badan Permusyawaratan Desa). Setelah itu panitia akan menyiapkan segala kebutuhan yang diperlukan untuk melakukan pemungutan suara seperti memvalidasi DPS (Daftar Pemilih Sementara) untuk dijadikan DPT (Daftar Pemilih Tetap), selain itu panitia juga menerima dan menyeleksi siapa saja yang mencalonkan diri agar menjadi calon tetap. Setelah itu, panitia akan mencetak surat suara dan menentukan hari pemilihan dan biasanya pemilihan dilakukan di 1 (satu) TPS (Tempat Pemungutan Suara), pemilihan dilakukan sekitar pukul 08.00 sampai pukul 13.00 waktu setempat kemudian dilakukan penghitungan suara sampai selesai. Cara ini tergolong sudah biasa dan mempunyai beberapa permasalahan seperti banyaknya suara yang masih blangko (Suara Tidak Sah), Melihat kegiatan tersebut maka penulis tertarik Membangun sistem pemungutan suara secara elektronik (e-Voting) pada pemilihan kepala desa dengan menggunakan teknologi SMS gateway. Dengan adanya sistem ini diharapkan dapat membuat sistem yang cepat dan efektif dalam pemungutan dan perhitungan suara. Diharapkan dengan dibuatnya sistem ini dapat memberikan kesempatan memilih bagi pemilih yang ada pada daftar pemilih yang berada di luar desa seperti Pelajar/Mahasiswa.

\section{METODOLOGI PENELITIAN}

\subsection{Metode Pengembangan Sistem}

Dalam melakukan penelitian ini untuk mengumpulkan data dan informasi dilihat dari jenis datanya yaitu:

a. Data Primer

Yaitu data yang dikumpulkan secara langsung dari objek penelitian.

b. Data Sekunder

Yaitu data yang dikumpulkan dengan cara membaca dan mempelajari masalah yang berhubungan dengan objek serta bersumber dari buku-buku, laporan akhir yang relevan.

\subsection{Metode Pengembangan Sistem}

Metode pengembangan sistem yang digunakan adalah Model Spiral, Menurut (Pressman, 2012), Model Spiral Pertama kali diperkenalkan oleh Barry Boehm [Boe88]. Model spiral merupakan suatu model proses perangkat lunak evolusioner yang 
menggabungkan pendekatan prototyping yang bersifat iteratif dengan aspek - aspek sistematis dan terkendali yang kita jumpai pada model air terjun (waterfall).

Menggunakan model spiral, perangkat lunak dikembangkan mengikuti sejumlah peluncuran produk yang bersifat evolusioner. Selama tahap yang lebih awal, produk/perangkat lunak yang diluncurkan mungkin berupa sebuah model atau suatu prototipe. Pada langka-langkah iterasi berikutnya versi-versi perangkat lunak yang semakin lengkap akan dihasilkan.

a. Komunikasi

Aktivitas ini berguna untuk membangun komunikasi yang efektif antara pengembang (developer) dan pelanggan (customer).

b. Perencanaan

Aktivitas ini diperlukan untuk pembuatan prakiraan-prakiraan, penjadwalan, analisis terhadap risiko-risiko perangkat lunak serta mendefinisikan sumber daya, waktu dan informasi yang berkaitan dengan proyek.

c. Pemodelan

Aktivitas ini diperlukan untuk membangun satu atau lebih representasi dari aplikasi perangkat lunak (dapat juga berupa prototipe) atau membuat analisis sistem yang berjalan dan membuat perancangan sistem yang diusulkan.

d. Konstruksi

Aktivitas ini dibutuhkan untuk membuat kode program, menguji, melakukan instalasi, dan menyediakan dukungan terhadap user (misalnya dari segi dokumentasi dan pelatihan)

e. Penyerahan sistem

Aktivitas ini dibutuhkan untuk mengirimkan program dan kemudian mendapatkan umpan balik berdasarkan evaluasi representasi perangkat lunak yang dihasilkan dari proses rekayasa dan diimplementasikan pada tahap instalasi. Berikut adalah Gambar 1 model spiral.

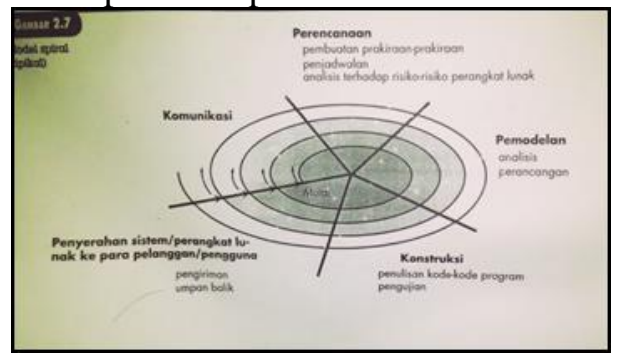

Gambar 1. Ilustrasi Model Spiral

Setiap wilayah kerja terdiri dari kumpulan pekerjaan (Task Set) yang tergantung pada karakteristik proyek yang sedang dikerjakan. Semakin besar suatu proyek maka kumpulan pekerjaan di dalam setiap wilayah kerja juga semakin banyak. Model spiral dilakukan searah dengan jarum jam di mulai dari sumbu proyek. Sumbu proyek dapat digunakan sebagai awal iterasi ataupun evaluasi dari iterasi yang sudah dilakukan. Pada Gambar 1 setiap wilayah kerja dibedakan dengan warna wilayah, dimana setiap wilayah berputar dengan urutan kerja tertentu. Pada model ini, hasil akhir dan evaluasi dari sebuah wilayah kerja akan menjadi inisiasi dari wilayah kerja berikutnya.

Model spiral menyediakan kemungkinan untuk pengembangan perangkat lunak yang cepat, yang bergerak dari versi perangkat lunak yang kurang lengkap menjadi versi yang semakin lengkap. Sehingga tidak diperlukan pembangunan ulang pada aplikasi jika ada perubahan sistem.

\subsection{Pengujian Kotak Hitam (Black-Box Testing)}

Menurut (Sukamto, R. A., \& Shalahuddin, M., 2013), Black-Box Testing yaitu menguji perangkat lunak dari segi spesifikasi fungsional tanpa menguji desain dan kode program. Pengujian dimaksudkan untuk mengetahui apakah fungsi-fungsi, masukan, dan keluaran dari perangkat lunak sesuai dengan spesifikasi yang dibutuhkan. 
Pengujian kotak hitam dilakukan dengan membuat kasus uji yang bersifat mencoba semua fungsi dengan memakai perangkat lunak apakah sesuai dengan spesifikasi yang dibutuhkan. Kasus uji yang dibuat untuk melakukan pengujian kotak hitam harus dibuat dengan kasus benar dan kasus salah, misalkan untuk kasus proses login maka kasus uji yang dibuat adalah:

a. Jika user memasukkan nama pemakai (username) dan kata sandi (password) yang benar.

b. Jika user memasukkan nama pemakai (username) dan kata sandi (password) yang salah, misalnya nama pemakai benar tapi kata sandi salah, atau sebaliknya, atau keduanya salah.

\section{4 e-Voting}

Menurut (Rokhman, 2011) e-Voting (Electronic voting) adalah proses pemilihan umum yang memungkinkan pemilih untuk mencatatkan pilihannya yang bersifat rahasia secara elektronik yang teramankan.

\subsection{SMS Gateway}

Menurut (Maulana, 2015), SMS Gateway merupakan sebuah sistem aplikasi yang digunakan untuk mengirim dan atau menerima $S M S$, dan biasanya digunakan pada aplikasi bisnis, baik untuk kepentingan broadcast promosi, servis informasi terhadap pengguna, penyebaran content produk/jasa dan lain-lain, (Handayani, 2012), menjelaskan bahwa SMS Gateway adalah sebuah perangkat atau sistem yang mampu menangani operasi dasar $S M S$ (mengirim, menerima, membaca dan menghapus $S M S$ ) yang berada diluar jangkauan GSM standar. Jadi SMS Gateway adalah sebuah aplikasi dan perangkat yang dapat mengoperasikan fungsi dari operasi dasar Mengirim, menerima, membaca dan menghapus SMS dan ada beberapa fitur tambahan seperti Autoreply, SMS broadcast, dan lain lain.

\subsection{Unified Modeling Language (UML)}

Pada perancangan UML ada 3 diagram yang dibuat yakni :

\subsubsection{Use Case Diagram}

Pada gambar 2 dijelaskan bahwa hak akses sepenuhnya ada pada admin yakni dapat mengelola data BPD, mengelola data Panitia, mengelola data Pemilih / DPT (Daftar Pemilih Tetap), mengelola data informasi, mengelola data Calon, mengelola format autoreply, mencetak laporan, mencetak undangan pemilihan. Adapun proses pengolahan data-data yaitu input, mengedit, menghapus, melihat dan mencari data. Sedangkan admin pemilihan memulai pemilihan dan memanajemen sms, dari sms masuk, sms keluar ataupun sms terkirim. Sedangkan untuk BPD bertugas mengelola data panitia yakni menambah, menghapus, mengubah da mencari data panitia dengan melakukan login terlebih dahulu, dan juga BPD menerima laporan hasil pemilihan dari panitia untuk di sampaikan kepada camat yang tembus ke Bupati. Selanjutnya untuk panitia memiliki tugas mengelola data Pemilih / DPT (Daftar Pemilih Tetap), mengelola data informasi, mengelola data Calon, mengelola format autoreply dengan menambah, mengubah atau menghapus dan mencari data yang dikelola, kemudian panitia juga bertugas membuat dan mencetak laporan yang akan di berikan kepada BPD berupa kertas (hard copy) berupa laporan data DPT, laporan data panitia, laporan data calon dan laporan hasil pemilihan. Kemudian panitia mencetak undangan pemilihan untuk diberikan kepada DPT berupa kertas juga. Setelah itu pemilih dalam hal ini DPT (Daftar Pemilih Tetap) akan melakukan pemilihan melalui SMS berdasarkan Format SMS yang telah ada di undangan yang diterima sebelum pemilihan dilangsungkan. Sedangkan untuk pengunjung hanya bisa melihat informasi dan tidak bisa melakukan login. 


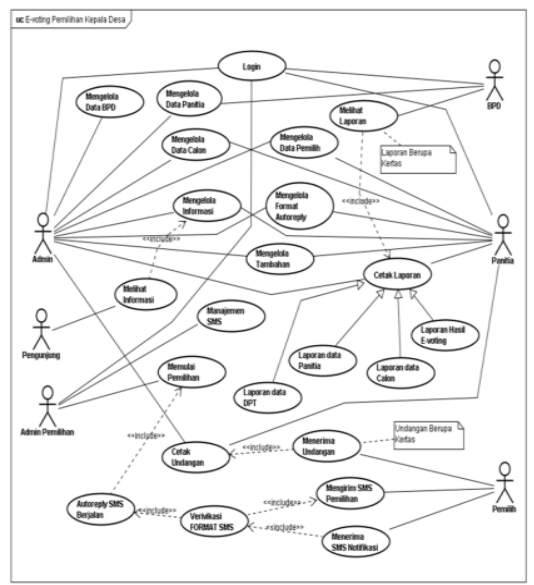

\section{Gambar 2. Use Case Diagram Sistem Yang Diusulkan}

\subsubsection{Activity Diagram}

Activity diagram menggambarkan workflow (aliran kerja) atau aktivitas dari sebuah sistem atau proses bisnis atau menu yang ada pada perangkat lunak. Berikut adalah desain activity diagram dari sistem yang diusulkan.

a. Activity diagram untuk admin

Activity Diagram untuk Admin ini menjelaskan proses Admin melakukan login terlebih dahulu, kemudian sistem akan mengecek username dan password yang diinputkan admin ke dalam database, jika benar maka akan tampil pilih menu, jika salah maka akan tampil pemberitahuan bahwa username dan password salah kemudian silahkan untuk login kembali. Jika login berhasil Admin dapat memilih menu kelola data BPD, kelola data panitia, dan lain-lain. Untuk keluar dari sistem, admin melakukan logout.

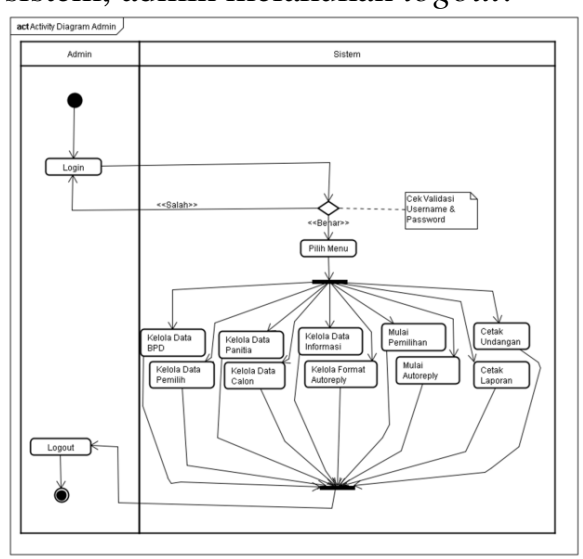

\section{Gambar 3. Activity Diagram Admin}

b. Activity Diagram untuk Badan Permusyawaratan Desa (BPD)

Activity Diagram BPD ini menjelaskan proses BPD melakukan login terlebih dahulu, kemudian sistem akan mengecek username dan password yang diinputkan BPD ke dalam database, jika benar maka akan tampil pilih menu, jika salah maka akan tampil pemberitahuan bahwa username dan password salah kemudian silahkan untuk login kembali. Jika login berhasil BPD dapat memilih menu kelola data panitia yang berfungsi untuk menginput, mengubah, mengedit dan mencari data. Untuk keluar dari sistem, BPD melakukan logout. 


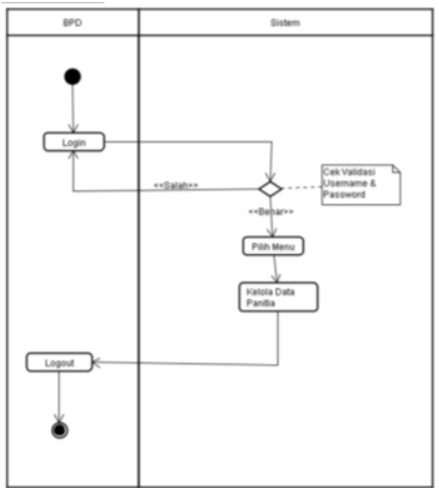

\section{Gambar 4. Activity Diagram Badan Permusyawaratan Desa (BPD)}

c. Activity Diagram Panitia

Activity Diagram panitia ini menjelaskan proses panitia melakukan login terlebih dahulu, kemudian sistem akan mengecek username dan password yang diinputkan panitia ke dalam database, jika benar maka akan tampil pilih menu, jika salah maka akan tampil pemberitahuan bahwa username dan password salah kemudian silahkan untuk login kembali. Jika login berhasil panitia dapat memilih menu kelola data pemilih, kelola data calon, dan lain-lain. Untuk keluar dari sistem, panitia melakukan logout.

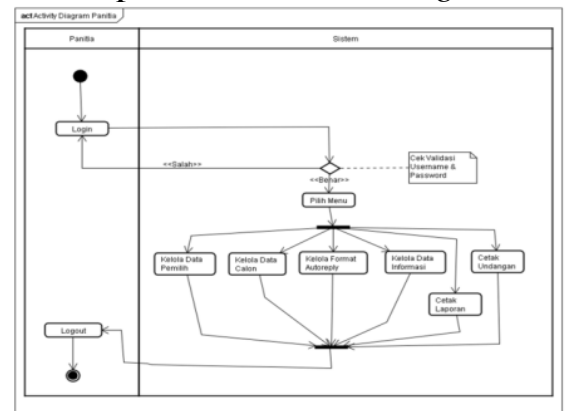

Gambar 5. Activity Diagram Panitia

d. Activity Diagram Pemilih

Activity Diagram pemilih ini menjelaskan proses pemilih kepala desa melalui SMS, jika ada sms masuk di tabel inbox dengan status proses false maka sistem akan otomatis mengecek format sms, jika format sms benar maka akan akan ada sms notifikasi benar, pemilih dinyatakan telah melilih dan akan menyimpan vote, jika format sms salah maka akan ada sms notifikasi salah dan pemilih dapat memilih sampai benar.

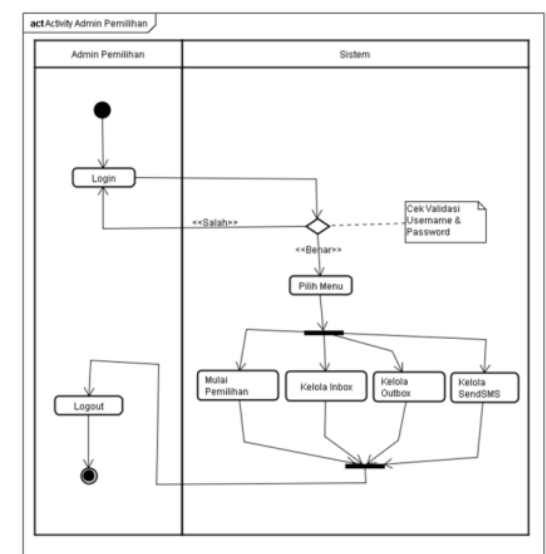

Gambar 6. Activity Diagram Pemilih 
e. Activity Diagram Admin Pemilihan

Activity Diagram admin pemilihan ini berfungsi untuk memulai pemilihan (proses autoreply) agar sistem dapat membalas otomatis dan memproses otomatis $e$-Voting secara sms, selain itu dapat memanajemen sms berupa sms masuk, kontak keluar dan sms terkirim. Untuk keluar dari sistem, panitia melakukan logout.

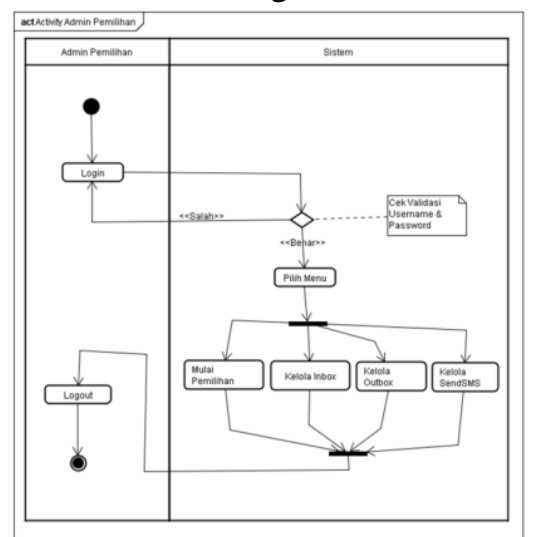

\section{Gambar 7. Activity Diagram Admin Pemilih}

\subsubsection{Class Diagram}

Class diagram menunjukkan hubungan dan kolaborasi antar class dalam sistem yang sedang dibangun. Class Diagram aplikasi e-voting dapat dilihat pada gambar 8 .

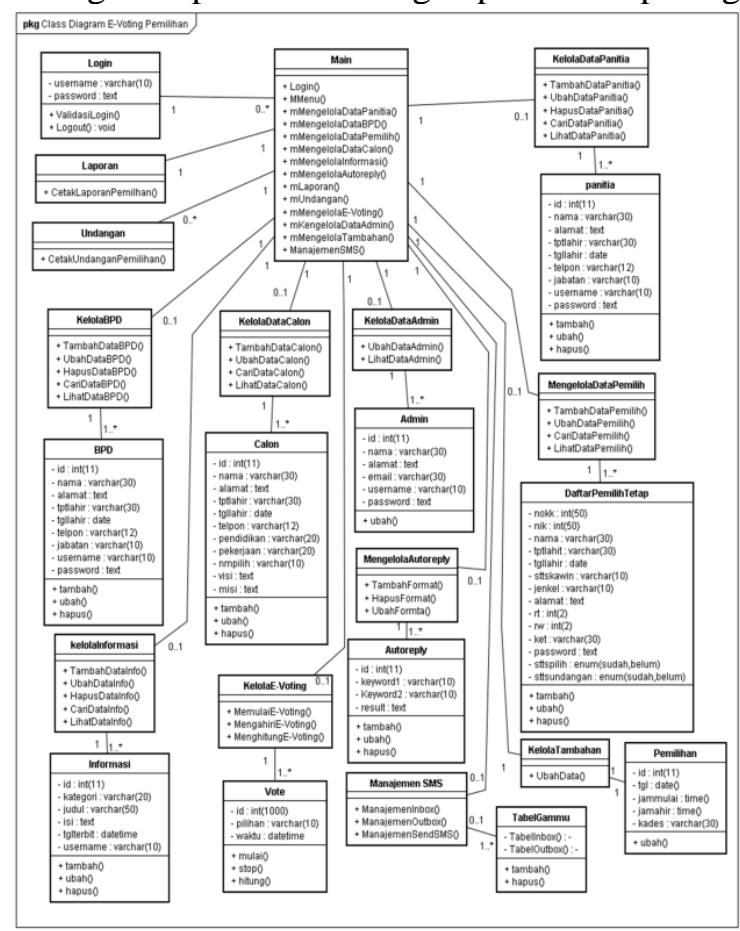

Gambar 8. Class Diagram Yang Diusulkan

\subsection{Perancangan Antarmuka}

Perancangan antarmuka merupakan desain tampilan atau antarmuka dari program yang akan dibangun. Tampilan ini akan menjadi komunikasi antara pengguna dan sistem 


\subsubsection{Desain Halaman Utama}

Desain form kelola Halaman Utama yang diusulkan adalah sebagai berikut, Desain halaman utama menampilkan halaman pembuka pada website e-voting. Misalnya ucapan selamat datang dan bisa juga menampilkan berita/informasi. Berikut desain halaman utama yang diusulkan.

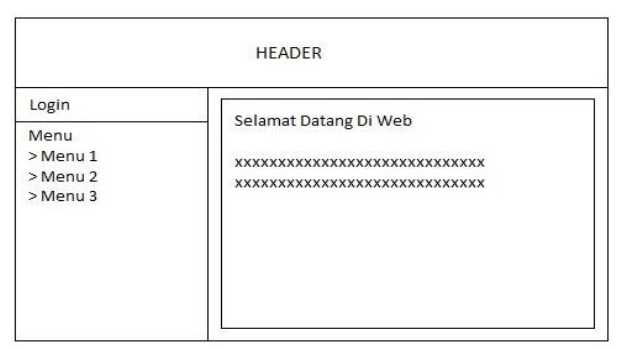

Gambar 9. Desain Halaman Utama

Gambar 9. merupakan desain halaman utama website yang memiliki menu login dan home Pada halaman awal juga ditampilkan berita terkini dan dan grafik pemilihan berisi info grafik pemilihan berdasarkan vote.

Selain itu aka dibuatkan beberapa desain antarmuka, yaitu:

1) Desain Halaman Utama Admin.

2) Desain Form Kelola Data BPD.

3) Desain Form Kelola Data Panitia.

4) Desain Form Kelola Informasi.

5) Desain Form Data Pemilih.

6) Desain Form Auto Replay.

7) Desain Form Cetak Laporan.

8) Desain Laporan DPT (Daftar Pemilih Tetap).

9) Desain Laporan Data Calon Kepala Desa.

\section{HASIL DAN PEMBAHASAN}

Hasil dari analisis dan desain pada penjelasan sebelumnya akan dibahas berdasarkan tahapan metode pengembangan sistem yang digunakan penulis yakni metode spiral, yang terdiri dari tahapan konstruksi dan tahapan penyerahan ke pelanggan.

\subsection{Konstruksi (Construction)}

Pada tahapan ini Aktifitas yang dilakukan adalah menkode program, menguji, melakukan instalasi, dan menyediakan dukungan terhadap user (misalnya dari segi dokumentasi dan pelatihan).

\subsubsection{Tampilan Service Gammu}

Berikut ini tampilan memulai service gammu dengan perintah Gammu-smsd -c smsdrc -i. Jika berhasil maka akan tampil pesan seperti gambar berikut:

c: \Gammu \bin>gammu-smsd -c smsdrc - s
Service GammusmsD started sucessfully
$c: \backslash G a m m \backslash$ bin

Gambar 10. Memulai Service Gammu

\subsubsection{Halaman Utama}

Halaman utama merupakan halaman awal website e-voting pemilihan kepala desa. Berikut tampilan halaman utama website: 


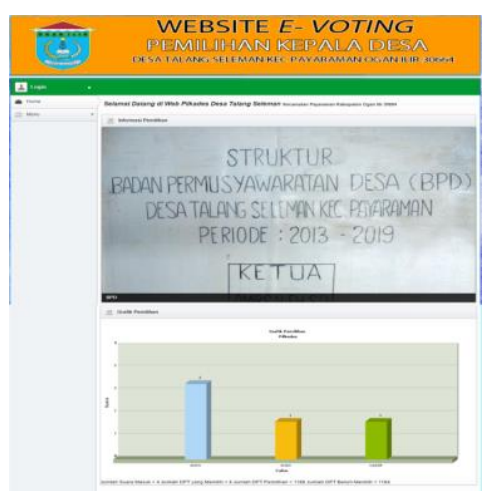

Gambar 11. Tampilan Halaman Utama

\subsubsection{Halaman Admin}

Gambar 12 merupakan halaman admin. Admin mempunyai hak akses penuh terhadap sistem, admin dapat melakukan kelola data BPD, kelola data panitia, kelola data informasi, kelola data calon. Kelola data pemilih, cetak laporan, dan lain-lain:

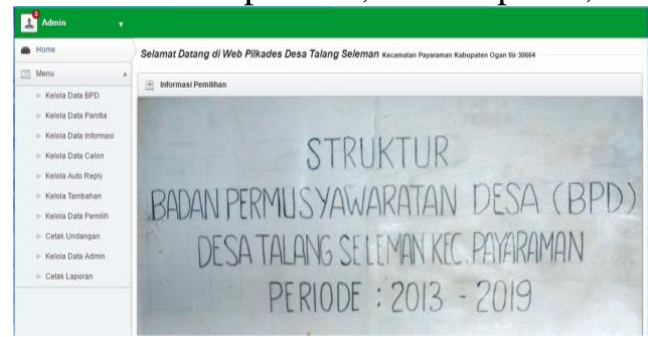

Gambar 12. Halaman Admin

\subsubsection{Halaman BPD}

Gambar 13 halaman BPD. Pada halaman BPD terdapat dua menu yang dapat di akses oleh BPD yaitu kelola data panitia dan kelola data informasi:

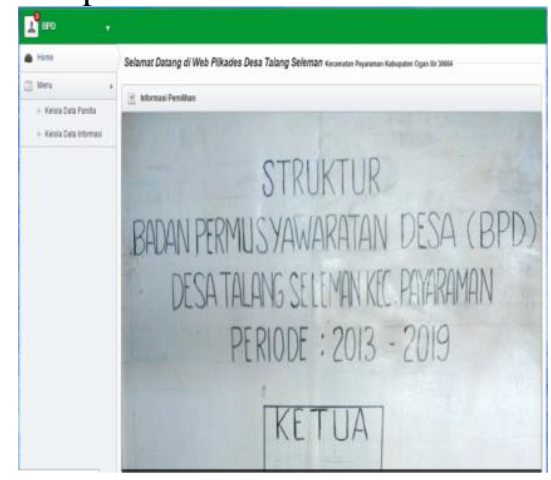

Gambar 13. Halaman BPD

\subsubsection{Halaman Panitia}

Pada gambar 14 merupakan tampilan halaman panitia. Setelah login panitia berhasil maka panitia dapat mengelola data-data seperti kelola data calon, kelola data pemilih, kelola auto reply, kelola data informasi, cetak undangan, dan lain- lain : 


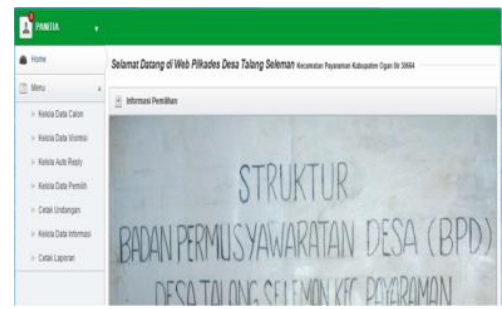

\section{Gambar 14. Halaman Panitia}

\subsubsection{Halaman Informasi}

Pada gambar 15 menjelaskan halaman kelola data informasi. Pada halaman ini admin bisa mengelola data informasi, seperti menginput, menghapus, mengubah data informasi

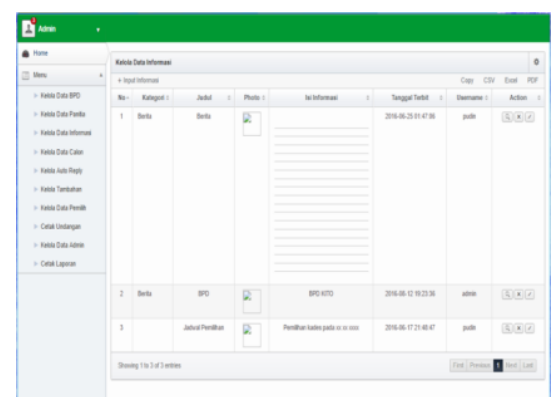

\section{Gambar 15. Halaman Informasi}

\subsubsection{Halaman Data Pemilih}

Pada gambar 16 menjelaskan halaman kelola data pemilih. Pada halaman ini panitia bisa mengelola data pemilih, seperti menginput, menghapus, mengubah data pemilih

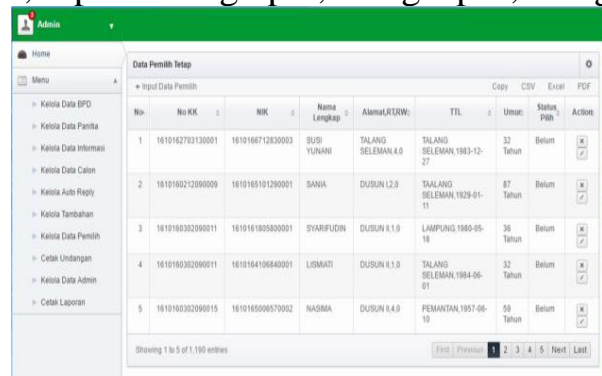

Gambar 16. Halaman Data Pemilih

\subsubsection{Laporan Cetak Undangan Pemilih}

Pada Gambar 17 menjelaskan undangan pemilihan yang berisi NIK, nama dan password dan berisi tentang hari, tanggal dan waktu pemilihan.

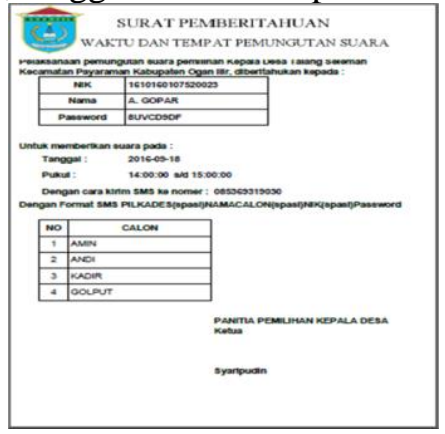

Gambar 17. Laporan Udangan Pemilih 


\subsubsection{Laporan Calon Kepala Desa}

Pada Gambar 18 menjelaskan laporan data calon kepala desa. Laporan ini berisi nama-nama calon kepala desa yang telah memenuhi persyaratan yang ditentukan

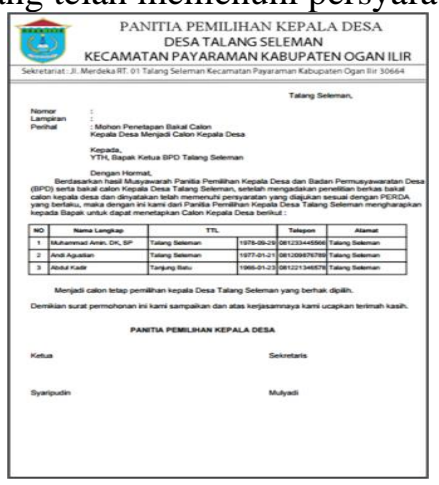

\section{Gambar 18. Laporan Calon Kepala Desa}

\subsubsection{Laporan Hasil $e$-Voting}

Pada gambar 19 menjelaskan laporan hasil e-voting yang berisi nama calon, total suara dan juga persentasi pemilihan

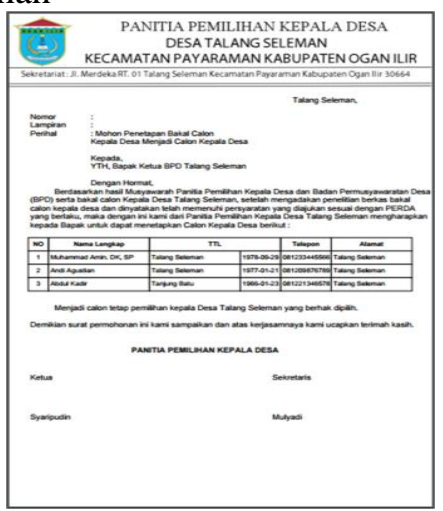

\section{Gambar 19. Halaman Laporan Calon Kepala Desa}

\subsubsection{Tampilah Hasil SMS Gateway}

Berikut ini tampilan proses sms masuk pada aplikasi dan sms handphone. Tampilan pada aplikasi terdiri dari 3 kategori:

a. Kotak Masuk Pada Menu Aplikasi

Pada gambar 20 dijelaskan semua kotak masuk yang berisi tanggal, nomor pengirim dan isi pesan.

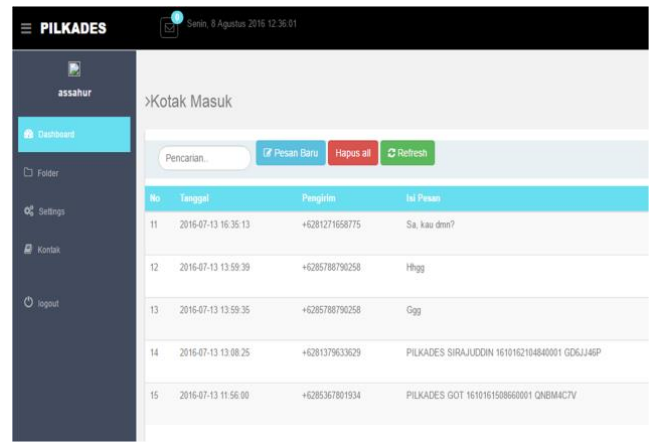

Gambar 20. Kotak Masuk Pesan Pada Aplikasi 
b. Kotak Keluar Pada Menu Aplikasi

Pada gambar 21 dijelaskan semua kotak keluar yang berisi tanggal, nomor pengirim dan isi pesan.

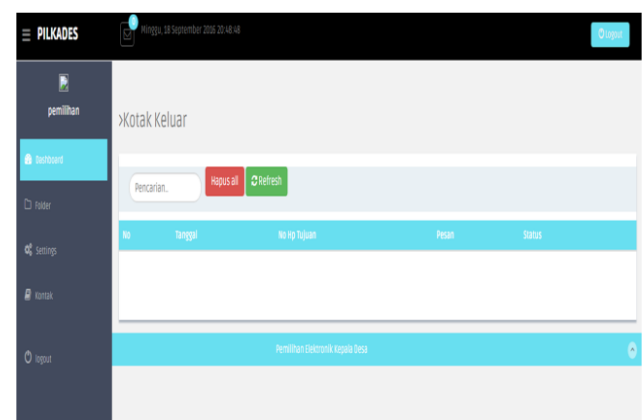

\section{Gambar 21. Kotak keluar Pesan Pada Aplikasi}

c. Pesan Terkirim Pada Menu Aplikasi

Pada gambar 22 dijelaskan semua pesan yang berhasil terkirim kepada penerimanya. Halaman ini berisi tanggal, nomor penerima, isi pesan, status terkirim

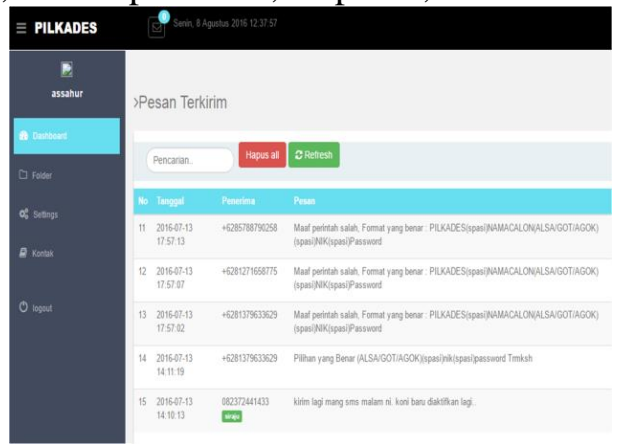

Gambar 22. Pesan Terkirim Pada Aplikasi

\section{KESIMPULAN}

Berdasarkan pembahasan yang telah diuraikan pada bab-bab sebelumnya, maka dapat diambil kesimpulan berikut ini:

1. Sistem informasi e-Voting pemilihan kepala desa ini dibangun berdasarkan hasil penelitian penulis menggunakan metode spiral, yakni salah satu metode pengembangan sistem yang ada. Dengan menggunakan metode ini penulis membangun sistem ini langsung observasi ke tempat penelitian dan melakukan riset kepada data beserta orang yang berpengalaman di bidang pemilihan di Desa Talang Seleman, sehingga sistem yang dibangun sesuai dengan kebutuhan di tempat penelitian.

2. Sistem yang dibangun diharapkan dapat membantu berkurangnya ataupun menghilangkan surat suara tidak sah (blangko) pada proses pemilihan yang selama ini masih dilakukan secara coblos / contreng, selain itu pembangunan sistem pemilihan elektronik ini diharapkan dapat memberikan pengetahuan kepada masyarakat atas kemajuan teknologi informasi dan menjadi motivasi bagi generasi penerus untuk mempelajari IPTEK (Ilmu Pengetahuan dan Teknologi).

3. Dengan dibuatnya sistem informasi $e$-Voting ini maka pemilihan kepala desa akan terjamin akurasi waktu mulai dan waktu berakhirnya pemilihan, dan juga dalam perhitungan suara yang dilakukan secara otomatis baik hasil sementara (quickcount) ataupun hasil akhir pemilihan (realcount) dapat dilihat masyarakat pada grafik pemilihan yang telah dibuat. Selai itu dalam penambahan, perubahan ataupun penghapusan data pemilih dapat dilakukan langsung tanpa harus meminta data ke kecamatan / kpu kabupaten, atau bisa dikatakan pengelolaan data dapat dilakukan secara 
mandiri seiring dengan dibentuknya otonomi desa. Laporan yang dapat dicetak pada sistem ini berupa laporan data panitia (penetapan panitia), laporan data calon (penetapan bakal calon menjadi calon tetap), laporan data pemilih tetap (penetapan mata pilih) dan laporan hasil pemilihan (penetapan hasil pemungutan suara elektronik.

\section{DAFTAR RUJUKAN}

Handayani, S. (2012). Membuat SMS Gateway dengan Delphi 7. Bandung: Widya Media.

Maulana, S. (2015). 5 Proyek Populer SMS Gateway . Jakarta: PT. Elex Media Komputindo.

Pressman, R. (2012). Rekayasa Perangkat Lunak (Pendekatan Praktisi) Edisi 7. Yogyakarta: Andi.

Rokhman, A. (2011). Prospek dan Tantangan Penerapan e-Voting di Indonesia. Seminar

Nasional Peran Negara dan Masyarakat dalam Pembangunan Demokrasi dan Masyarakat Madani di Indonesia, 1-11.

Saputra, A. (2011). Panduan Praktis Menguasai Database Server MySQL. Jakarta: PT. Elex Media Komputindo.

Sukamto, R. A., \& Shalahuddin, M. (2013). Rekayasa Perangkat Lunak Terstruktur dan Berorientasi Objek. Bandung: Informatika.

Sutabri, T. (2012). Konsep Sistem Informasi. Yogyakarta: Andi. 
28 | JUSIFO (Jurnal Sistem Informasi), p-ISSN: 2460-092X, e-ISSN: 2623-1662

Volume 3, Nomor 1, Juni 2017 